\title{
Consolidation of in-pit tailings
}

\author{
L. McDonald Coffey Mining, Australia
}

J.C. Lane Coffey Mining, Australia

\begin{abstract}
The use of mined out pits for tailings storage is becoming increasingly popular due to economic and environmental benefits. The main post closure issue with tailings deposition into in-pit facilities is the prediction of the settlement of the final surface in terms of time and magnitude of consolidation (settlement), as this governs when rehabilitation can commence and the type of rehabilitation to promote a free draining surface. Consolidation of in-pit tailings is influenced by factors such as tailings properties, pit geometry and permeability, and available drainage pathways. This paper presents the results of finite element modelling of various in-pit facilities to predict the consolidation and contributing factors. Case studies draw upon historical data from post closure pits from a range of tailings materials to allow the modelling to be correlated with actual field results.
\end{abstract}

\section{Introduction}

This study presents the tailings consolidation results of two in-pit case studies in Western Australia. The K1SE Pit, located at the Marymia Gold Mine approximately $200 \mathrm{~km}$ northeast of Meekatharra, and the Criterion Pit located at the Bulong Nickel Mine, approximately $30 \mathrm{~km}$ east of Kalgoorlie (Figure 1). The historical data from the two case studies is used to correlate finite element modelling as a method to predict consolidation and the contributing factors.

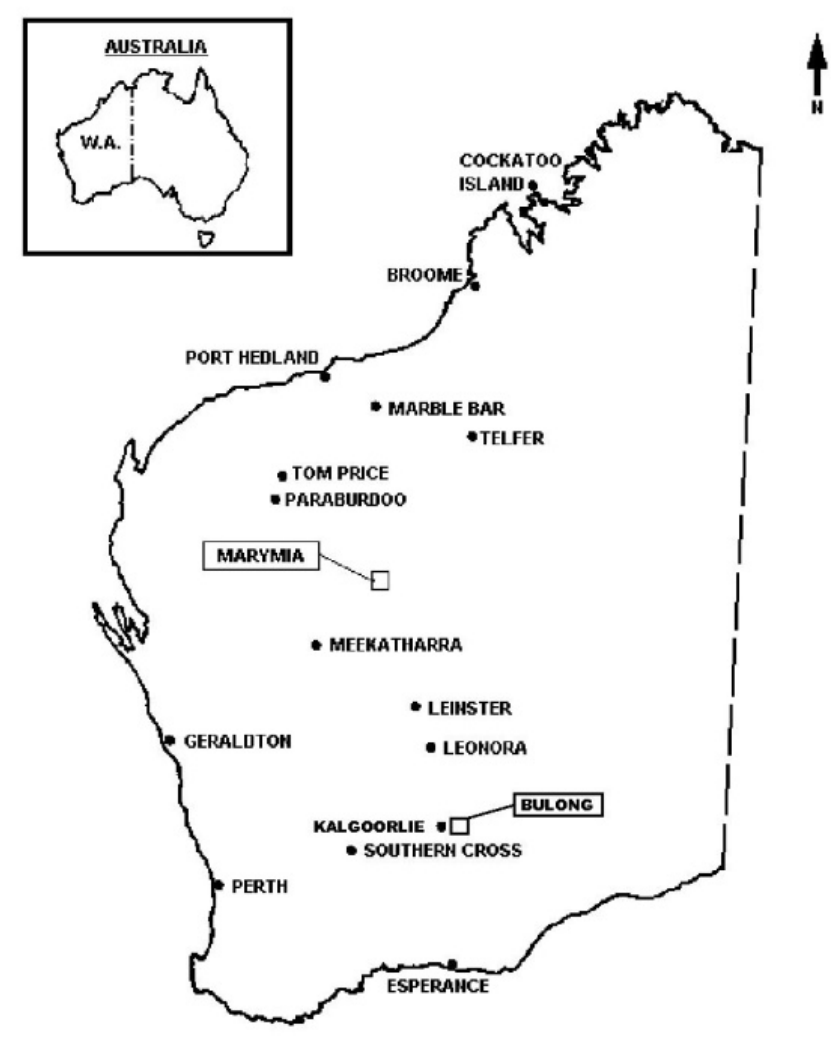

WESTERN AUSTRALIA

Figure 1 Location of Marymia and Bulong mine sites 
Previous studies regarding the consolidation of in-pit tailings (Anstey and Williams, 2007) estimate settling periods of up to 110 years for gold tailings and 2,000 years for laterite nickel tailings. This does not match what is evident in the field. Consolidation and therefore rehabilitation can be achieved in a reasonable short time period, post completion of tailings deposition, if the pit is operated well such that the recovery of supernatant water is maximised during the operational life of the pit. The amount of settlement that will occur in an in-pit facility is dependent on the tailings consolidation characteristics. The rate of consolidation is dependent on the permeability of the tailings, and available drainage pathways. The design of the water recovery system (pontoon mounted pump and/or underdrainage) is derived from the settling characteristics and consolidation characteristics of the tailings, and is essential for the success of an in-pit tailings storage facility to ensure consolidation is achieved in optimal time. Cyclic deposition can reduce the waiting period for rehabilitation as the tailings mass has the opportunity to consolidate throughout the operation of the facility.

\section{Case study 1 - K1SE Pit, Marymia Gold Mine}

\subsection{Background}

In December 1995, K1SE Pit was commissioned as a tailings storage facility. Tailings were deposited into K1SE on a continuous basis until October 1996, and then intermittently from August 1997 to November 1997 (Soil and Rock Engineering Pty Ltd, 1997). Details of the deposition history are presented in Table 1.

Table 1 K1SE pit tailings deposition

\begin{tabular}{lll}
\hline \multicolumn{2}{l}{ Dates of Operation } & Tonnes of Tailings Deposited \\
\hline 15 Dec 1995 & 4 Oct 1996 & 483,589 \\
16 Aug 1997 & 17 Aug 1997 & 3,650 \\
20 Aug 1997 & 26 Aug 1997 & 11,692 \\
6 Nov 1997 & 14 Nov 1997 & 14,913 \\
Total & & 513,844 \\
\hline
\end{tabular}

The ore extracted at the Marymia Gold Mine was mineralised, oxidised sheared ultramafic material and mineralised banded iron formation. Gold was extracted through the CIP process at the rate of 550,000 dry tonnes of tailings per annum. The tailings were deposited at $43 \%$ solids equivalent to a dry density of $0.60 \mathrm{t} / \mathrm{m}^{3}$, with $80 \%$ passing $75 \mu \mathrm{m}$.

\subsection{Site conditions}

Climatic conditions at K1SE Pit are typically semi-arid to arid, with an average annual rainfall, based on site data, of approximately $260 \mathrm{~mm}$ and average evaporation of 3,800 $\mathrm{mm}$ per year, based on Technical Report No. 65 Evaporation Data for Western Australia (Luke et al., 1988). The rainfall received at K1SE Pit over the two-year period of operation was $840 \mathrm{~mm}$.

Mining of K1SE pit commenced in October 1994, and was completed in May 1995. Minimal blasting was required to excavate the pit, leaving the talc chlorite schist on the northern side of the pit and the mafics on the west, close to their natural states. No tension cracking or evidence of pit wall failure was observed in the pit prior to deposition. Groundwater was encountered during excavation of K1SE pit $1 \mathrm{~m}$ above the base of the pit at RL596 mAHD. Regional groundwater was well below K1SE pit at RL586.7 mAHD.

During the operation of K1SE water levels in adjacent monitoring bores responded quickly to tailings deposition, rising rapidly and subsequently declining post deposition. Figure 2 presents the standing water levels in the monitoring bores from the beginning of deposition in December 1995 through to and beyond post-rehabilitation in 1999. The latest readings were in mid 2009. 


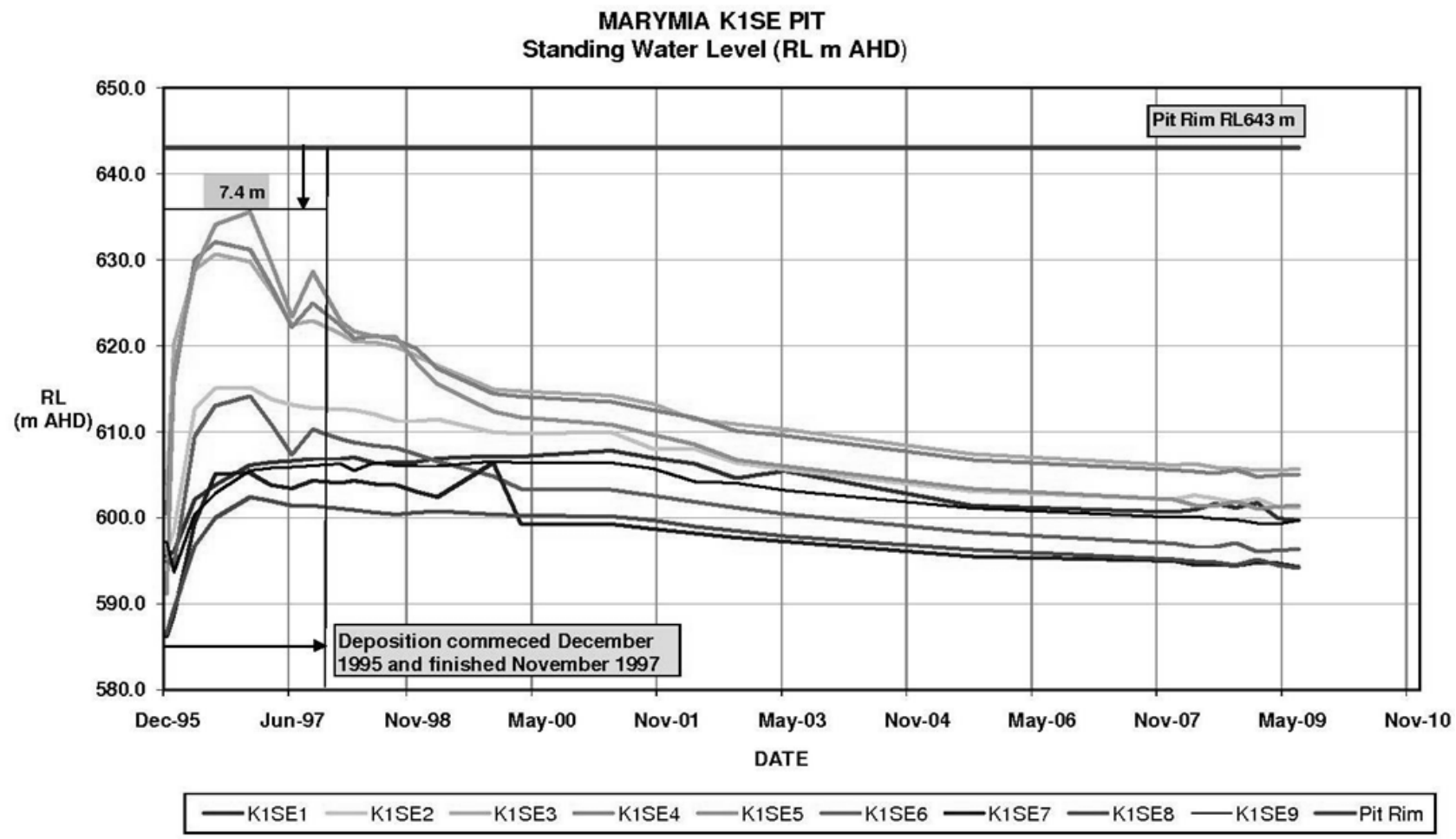

Figure 2 Standing water levels in monitoring bores adjacent to K1SE

\subsection{Design concept}

The tailings were discharged sub aerially into K1SE in the form of slurry via a single spigot placed over the rim of the pit in the southwest corner. Underdrainage in the K1SE pit was not included at the design stage due to the potential high water return off the tailings surface and the limited storage life. The supernatant water from the tailings was returned to the process plant for reuse via a pontoon-mounted pump. The return water volumes, as a percentage of water in the tailings slurry, range between $5 \%$, at the start of the in-pit disposal in December 1995 and 74\% for the month of April 1996 (Lane, 2000).

\subsection{Consolidation and rehabilitation}

The base of K1SE pit is at RL595 mAHD and the final tailings surface reached RL643 mAHD (centre of pit) in November 1997, resulting in a maximum tailings thickness of $48 \mathrm{~m}$. The initial deposition of tailings into K1SE reached RL643 mAHD in October 1996. The pit was not used until August 1997 allowing the tailings to dry and consolidate. The resulting settlement in this period ranged between 1.5 and $2 \mathrm{~m}$. It was then topped up intermittently until November 1997, when it reached the limiting RL 643 mAHD. In May 2005, Coffey Geosciences Pty Ltd conducted a geotechnical study obtaining tailings samples from the pit for laboratory testing. The settlement observed during the 2005 study since the final survey in November 1997, was estimated to be no more than $2 \mathrm{~m}$, based on the survey supplied (Figure 3 ). 


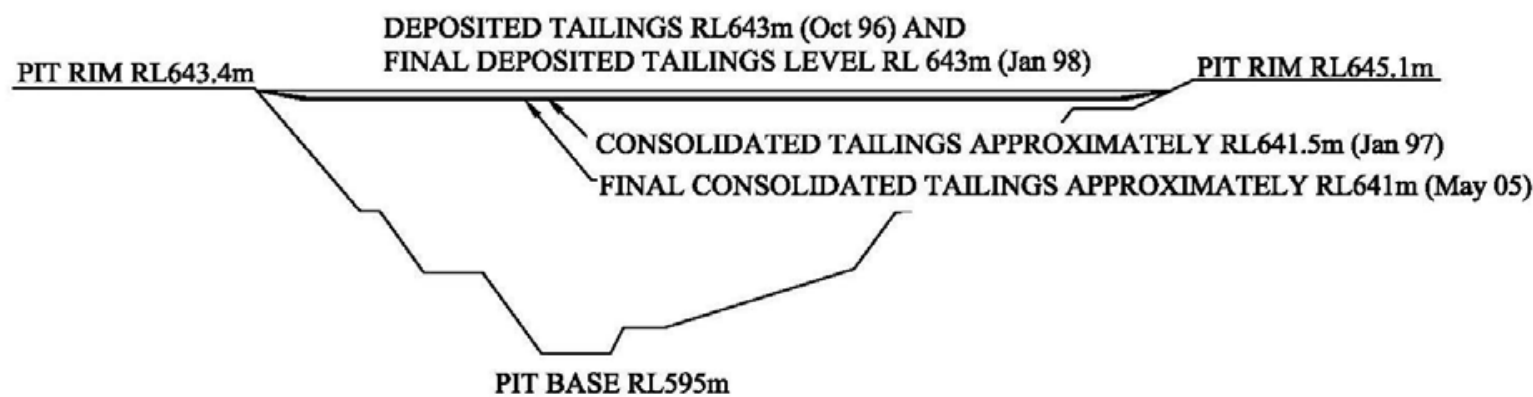

Figure 3 K1SE pit cross-section

The cyclic (refer to Table 2 for deposition periods) deposition into K1SE allowed the tailings to dry and consolidate throughout the storage life. This reduced the period for consolidation and the settlement after final deposition. The total post-deposition settlement of K1SE was approximately $4 \mathrm{~m}$, or less than $10 \%$ of the tailings thickness. Negligible settlement occurred at the boundary of the pit.

Table 2 K1SE tailings deposition periods

\begin{tabular}{lll}
\hline Deposition Period & \multicolumn{2}{c}{ Dates of Deposition } \\
\hline 1 & 15 Dec 1995 & 4 Oct 1996 \\
2 & 16 Aug 1997 & 17 Aug 1997 \\
3 & 20 Aug 1997 & 26 Aug 1997 \\
4 & 6 Nov 1997 & 14 Nov 1997 \\
\hline
\end{tabular}

The change in dry density throughout consolidation of K1SE is calculated from tonnes of tailings deposited and the surveyed volume of tailings in the pit. This is summarised in Table 3.

\section{Table 3 K1SE tailings dry density}

\begin{tabular}{ll}
\hline Dates of Measurement & Tailings Dry Density $\left(\mathbf{t} / \mathbf{m}^{\mathbf{3}}\right)$ \\
\hline March 1996 (during deposition) & 1.00 \\
October 1996 (after initial deposition) & 1.17 \\
August 1997 (after consolidation for 10 months) & 1.26 \\
January 1998 (end of deposition - consolidating for two months) & 1.40 \\
May 2005 & 1.60 \\
\hline
\end{tabular}

The dry density of the tailings increases as consolidation occurs and the volume decreases (settles). Desiccation of the tailings surface occurred during the drying and consolidating process of the K1SE pit. It was safe to walk to the centre of the pit by January 1998, two months after deposition ceased indicating rapid consolidation.

Rehabilitation of K1SE pit occurred in 2000 and by 2004 the surface successfully appeared a part of the natural landscape. Figures 4 and 5 show photographs taken in November 2009. 


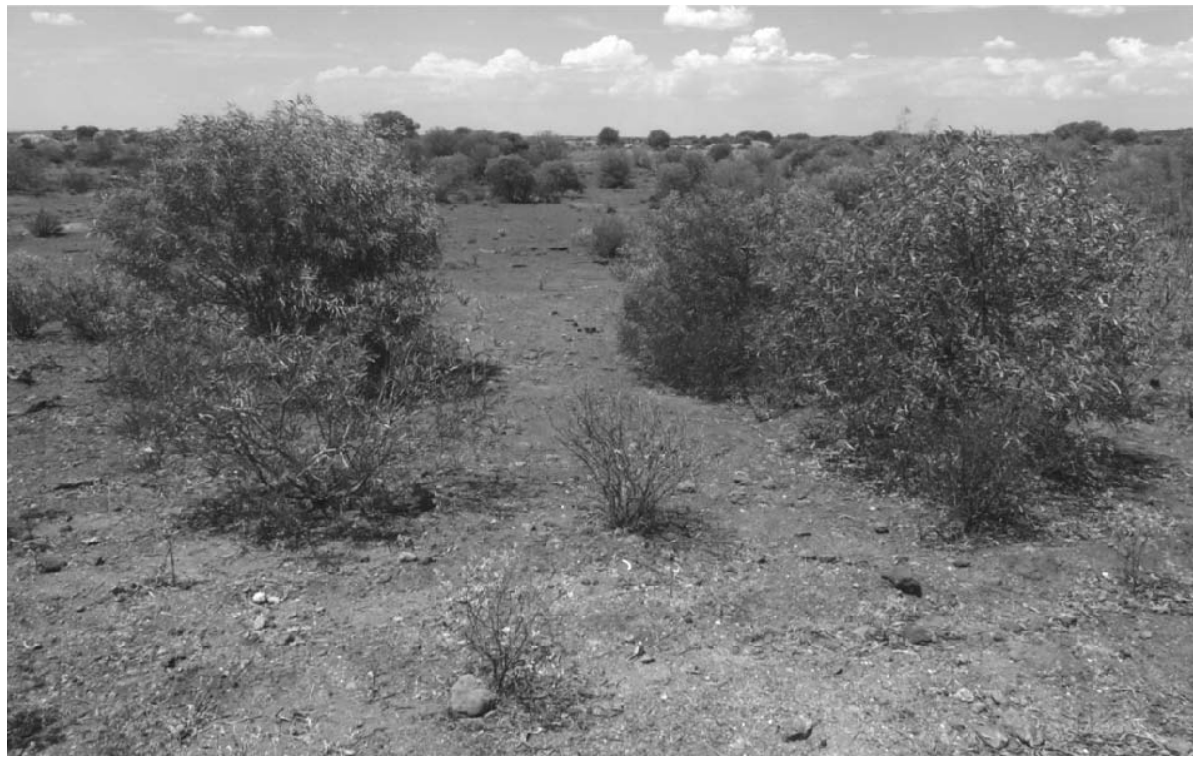

Figure 4 K1SE rehabilitated surface, 2009

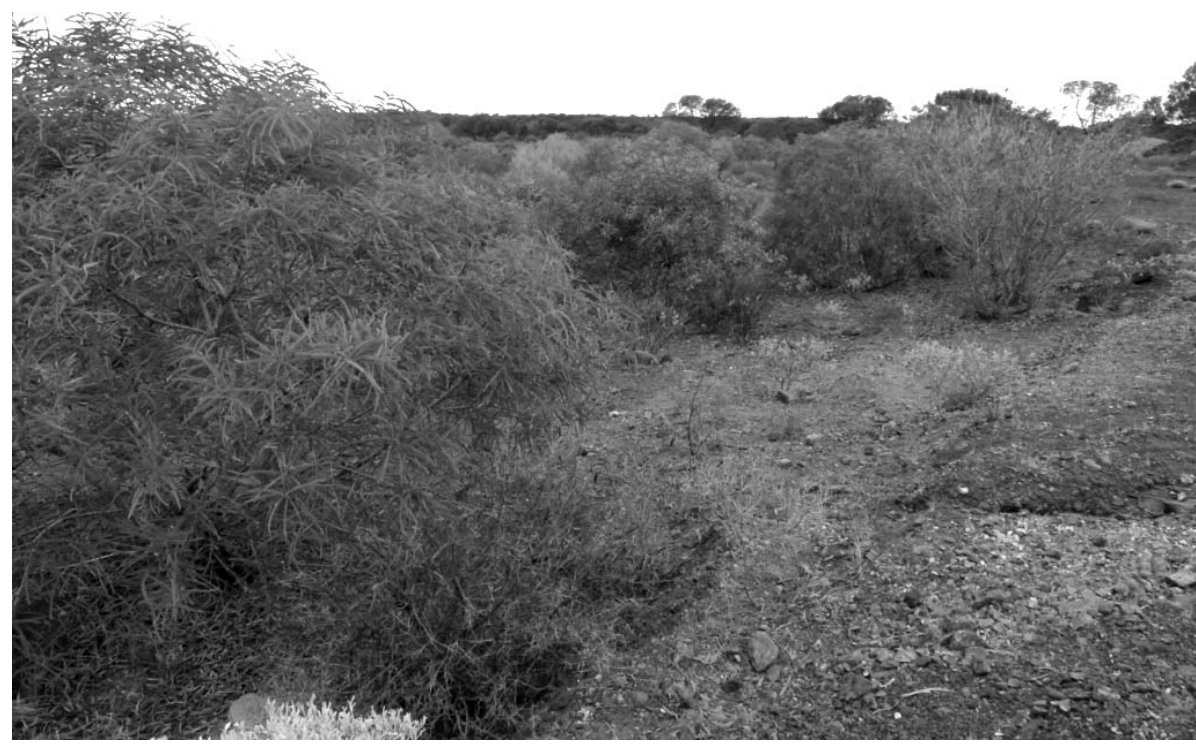

Figure 5 K1SE rehabilitated surface, 2009

\section{Case study 2 - Criterion Pit, Bulong Nickel Mine}

\subsection{Background}

In May 2002, the Criterion Pit was commissioned as a tailings storage facility. Tailings deposition commenced on a continuous basis until November 2002 (Soil and Rock Engineering Pty Ltd, 2004). Deposition tonnages and periods for Criterion Pit are presented in Table 4. 
Table 4 Criterion pit tailings deposition

\begin{tabular}{lll}
\hline \multicolumn{2}{l}{ Dates of Operation } & Tonnes of Tailings Deposited \\
\hline May 2002 & June 2002 & 41,746 \\
June 2002 & July 2002 & 55,671 \\
July 2002 & August 2002 & 161,329 \\
August 2002 & November 2002 & 184,571 \\
Total & & 401,571 \\
\hline
\end{tabular}

The ore extracted at the Bulong Nickel Mine was from oxidic ultramafic rocks limestone, clay and serpentinite styles. The lateritic nickel was extracted using high-pressure acid leach, solvent extraction electro-winning technology, resulting in approximately 700,000 dry tonnes of tailings per annum. The tailings were deposited at $20 \%$ solids, $80 \%$ passing $75 \mu \mathrm{m}$ and a dry density of $0.74 \mathrm{t} / \mathrm{m}^{3}$.

Laterite nickel tailings can cause problems with consolidation due to low dry density, high percent fines and a tendency to retain a high amount of moisture.

\subsection{Site conditions}

Climatic conditions at Criterion Pit are typically semi-arid, with hot dry summers and cool winters and an average annual rainfall of approximately $250 \mathrm{~mm}$, based on Kalgoorlie average rainfall. Evaporation consistently exceeds rainfall, with an average evaporation rate of $2,664 \mathrm{~mm}$ per year, based on site data (Class A Pan). The rainfall received at Criterion Pit over the period of operation was $36 \mathrm{~mm}$ and evaporation was $1,333 \mathrm{~mm}$.

Groundwater was not intercepted during exploration drilling or mining at the Criterion Pit. It was expected to be in excess of $50 \mathrm{~m}$ below the pit base. The geology in the pit consists primarily of smectite clays. These clays tend to desiccate after prolonged periods of exposure to the atmosphere, which resulted in 'rilling' of the pit walls. No cracking was evident in the pit prior to deposition. The slopes of the pit walls were generally at an angle of $45^{\circ}$.

During geotechnical investigations of Criterion Pit prior to deposition, it became apparent that the high plasticity clay and highly weathered rock in the pit walls were generally considered relatively impermeable.

\subsection{Design concept}

The tailings were discharged sub aerially into Criterion Pit in the form of a slurry via a single spigot placed over the rim at the southern end of the pit. Underdrainage was not considered in the design as the loss of water by seepage through the pit floor was expected to be low and the primary method of water recovery was to be a pontoon mounted pump. The collected supernatant water was pumped to the evaporation ponds using a pontoon mounted pump at the northern end of pit.

\subsection{Consolidation and rehabilitation}

The base of Criterion Pit was at RL360 mAHD and the final tailings surface reached approximately RL374.5 mAHD in November 2002, resulting in a maximum tailings thickness of $14.5 \mathrm{~m}$. CPT testing performed by Coffey Mining in April 2008 found low pore pressures in the tailings indicating about 95\% of consolidation had occurred ('consolidated' tailings). The final level of the tailings was approximately RL741 mAHD, settling 3.5 to $4 \mathrm{~m}$, or $28 \%$ of the tailings thickness, in less than five years, as presented in Figure 6. 


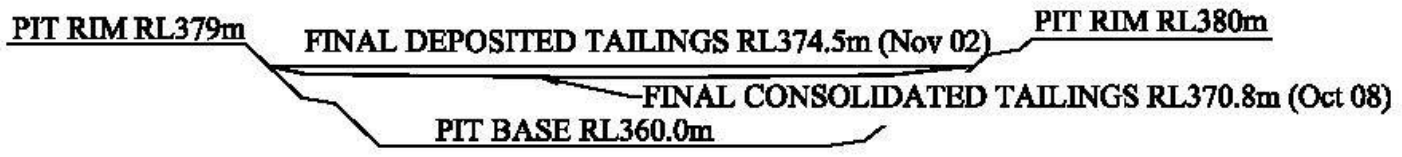

\section{Figure 6 Criterion Pit cross section}

Figure 7 shows the desiccation of the final surface in Criterion Pit, and the limited settlement that occurred at the pit wall boundary.

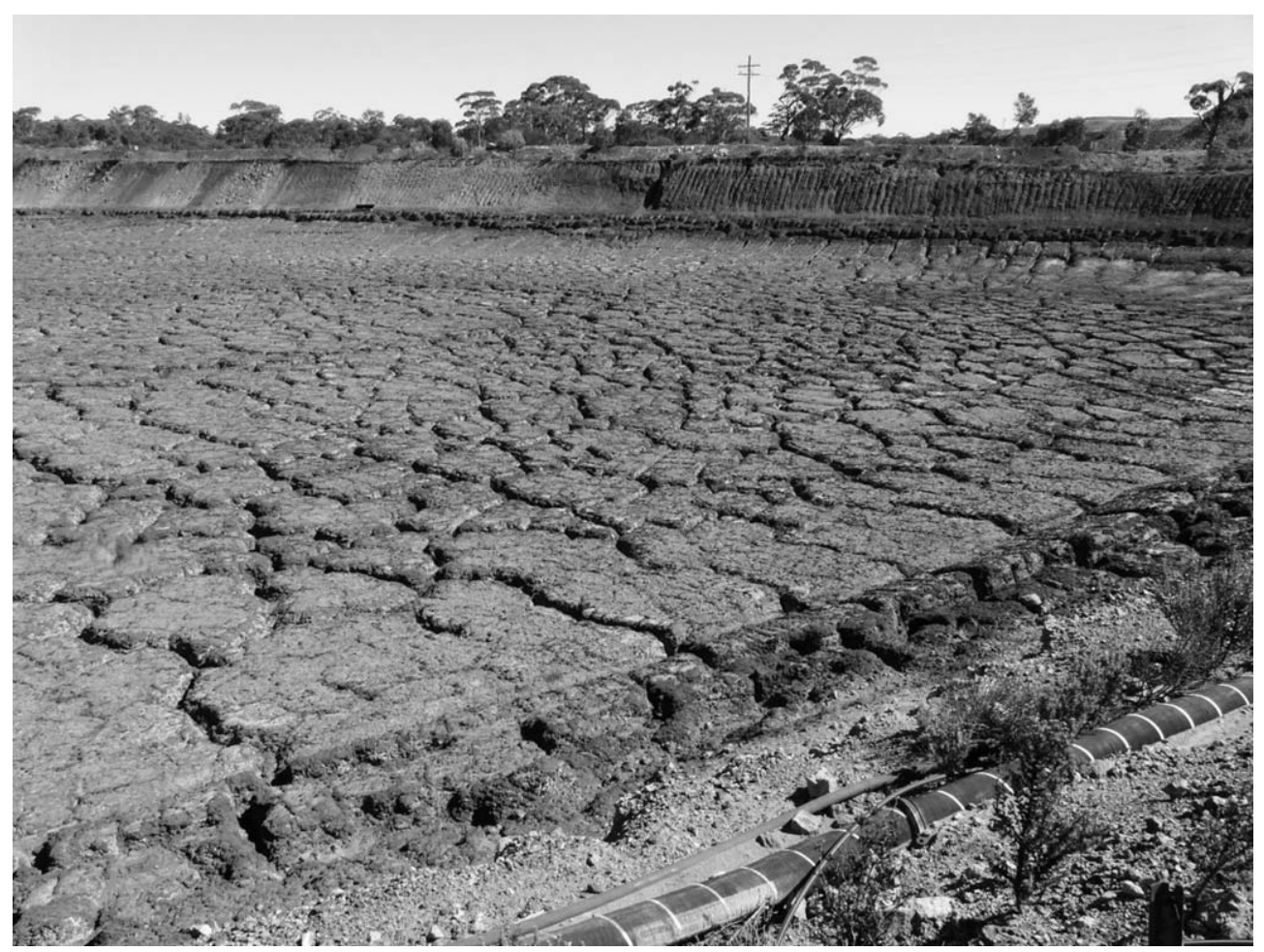

Figure 7 Criterion Pit photo, October 2008

The change in dry density throughout consolidation of Criterion Pit was calculated from tonnes of tailings deposited and the surveyed volume in the pit. This is summarised in Table 5.

\section{Table 5 Criterion tailings dry density}

\begin{tabular}{ll}
\hline Dates of Measurement & Tailings Dry Density $\left(\mathbf{t} / \mathbf{m}^{\mathbf{3}}\right)$ \\
\hline August 2002 (during deposition) & 0.74 \\
January 2003 (end of deposition - & \\
consolidating for two months) & 0.81 \\
April 2008 & 1.20 \\
\hline
\end{tabular}

No rehabilitation of the surface has been proposed at this stage. 


\section{$4 \quad$ Modelling methodology}

PLAXIS ${ }^{\circledR}$ is a two-dimensional finite element program used to model soil behaviour in a variety of geotechnical applications. In this study, PLAXIS ${ }^{\circledR}$ was used as it can create an advanced constitutive model taking into account non-linear and time-dependent behaviour of soils. The program also investigates both hydrostatic and non-hydrostatic pore pressures (changing pore pressures over time) in the soil, allowing excess pore pressures to be calculated iteratively.

\subsection{Model geometry}

For both the K1SE and Criterion Pits, the model geometry was based on a cross section from the location where the tailings thickness is a maximum; hence, settlement and the time for consolidation will also be a maximum. Refer to Figures 8 and 9. A second case (Case A) was analysed for K1SE Pit with the addition of a $1 \mathrm{~m}$ wide 'pit wall' section (i.e. a zone of higher permeability due to mining activities, refer to section 4.3) around the edge of the pit.

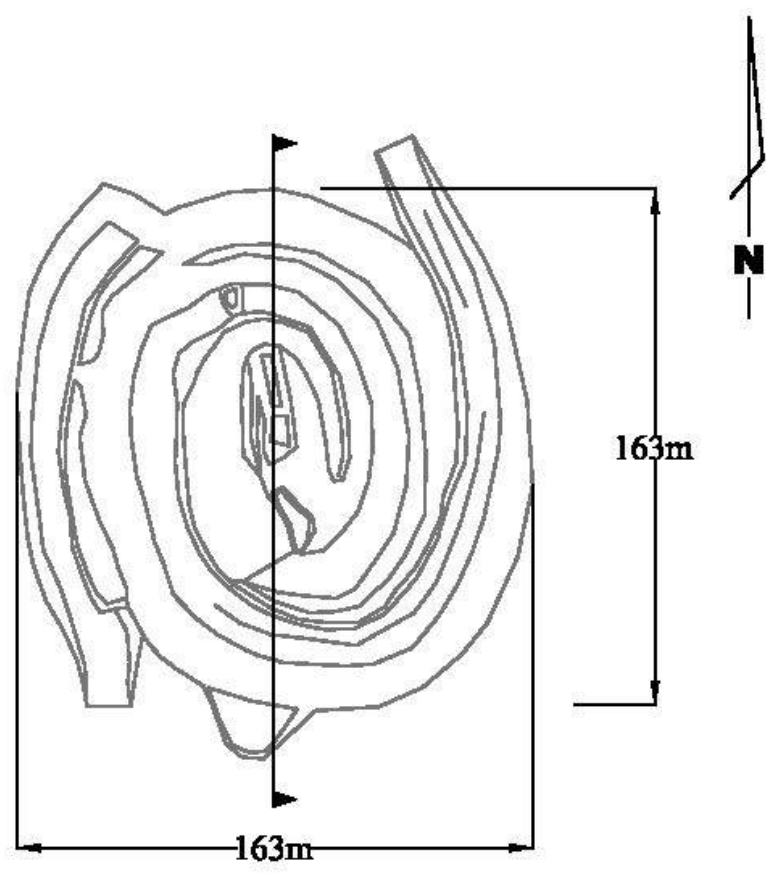

Figure 8 K1SE Pit

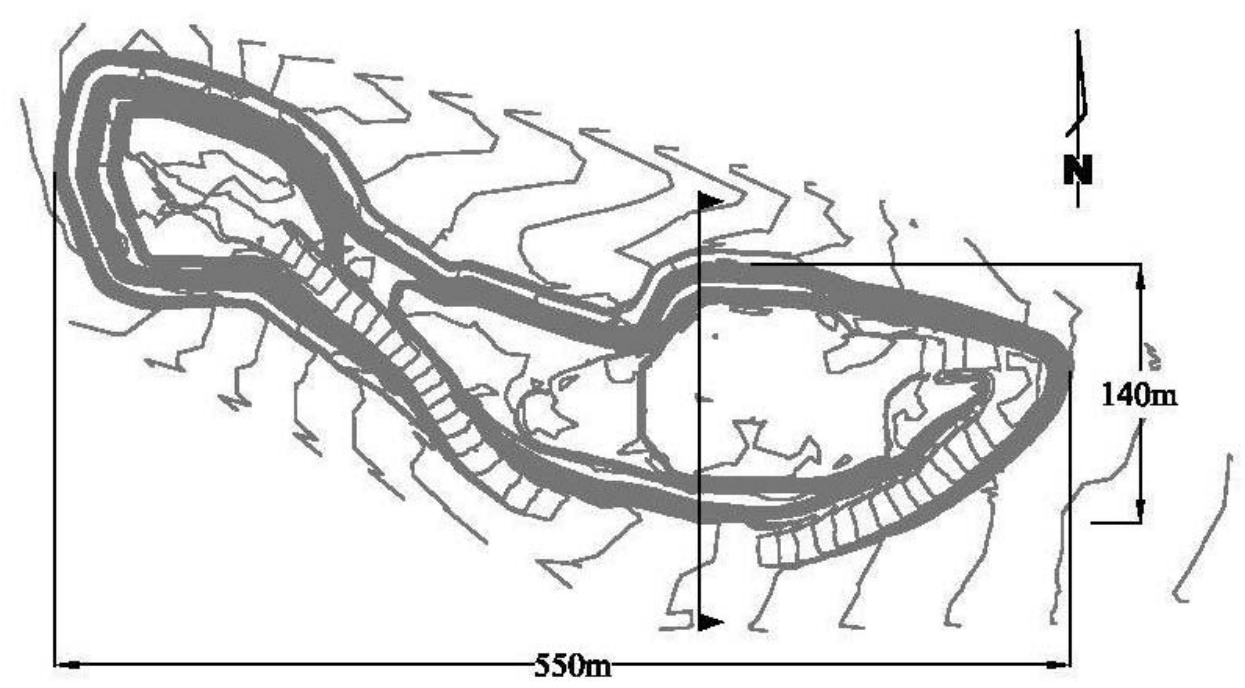

Figure 9 Criterion Pit 
In both case studies, total fixities (horizontal and vertical) were placed on the pit boundary to prevent movement of the pit walls. The pit boundaries, as seen in the field, were modelled as impermeable, preventing the dissipation of any excess pore pressures by setting a 'no consolidation' boundary.

\subsection{Material models}

The modified cam clay (MCC) material model in PLAXIS ${ }^{\circledR}$ was chosen for both case studies in this paper. The MCC model was formulated by researchers at Cambridge University to describe soft soil behaviour. It is an elastic plastic strain-hardening model based on critical state theory. Three important aspects of soil behaviour can be described by using the MCC model (Hammah, 2005): strength, compression or tendency to dilate (the change of volume that occurs with shearing), and the soil elements critical state in which unlimited deformations can occur without any changes in stress or volumes.

The MCC model follows the strain-hardening rule, allowing the yield surface to expand due to plastic strain. The soil reaches the yield surface cap once the soil is at critical state and unlimited plastic shear strains develop with no volumetric strain. Loading of the soil cannot proceed once it reaches the yield surface cap.

Tailings material consists of a large proportion of voids filled with water. As consolidation occurs some of these voids are compressed, and water content and volume decreases. The rate at which the tailings consolidate largely depends on the permeability of the tailings.

The MCC model assumes the soil is compressed under isotropic loading $\left(p^{\prime}=\sigma_{1}^{\prime}+\sigma_{2}^{\prime}+\sigma_{3}^{\prime}\right)$ and perfectly drained conditions. These conditions create a linear relationship between specific volume (v) and the natural logarithm of the stress applied (ln p'). This is known as the normal compression line, and the unloadingreloading line (Muir Wood, 1991). Refer to Figure 10 for the MCC model.

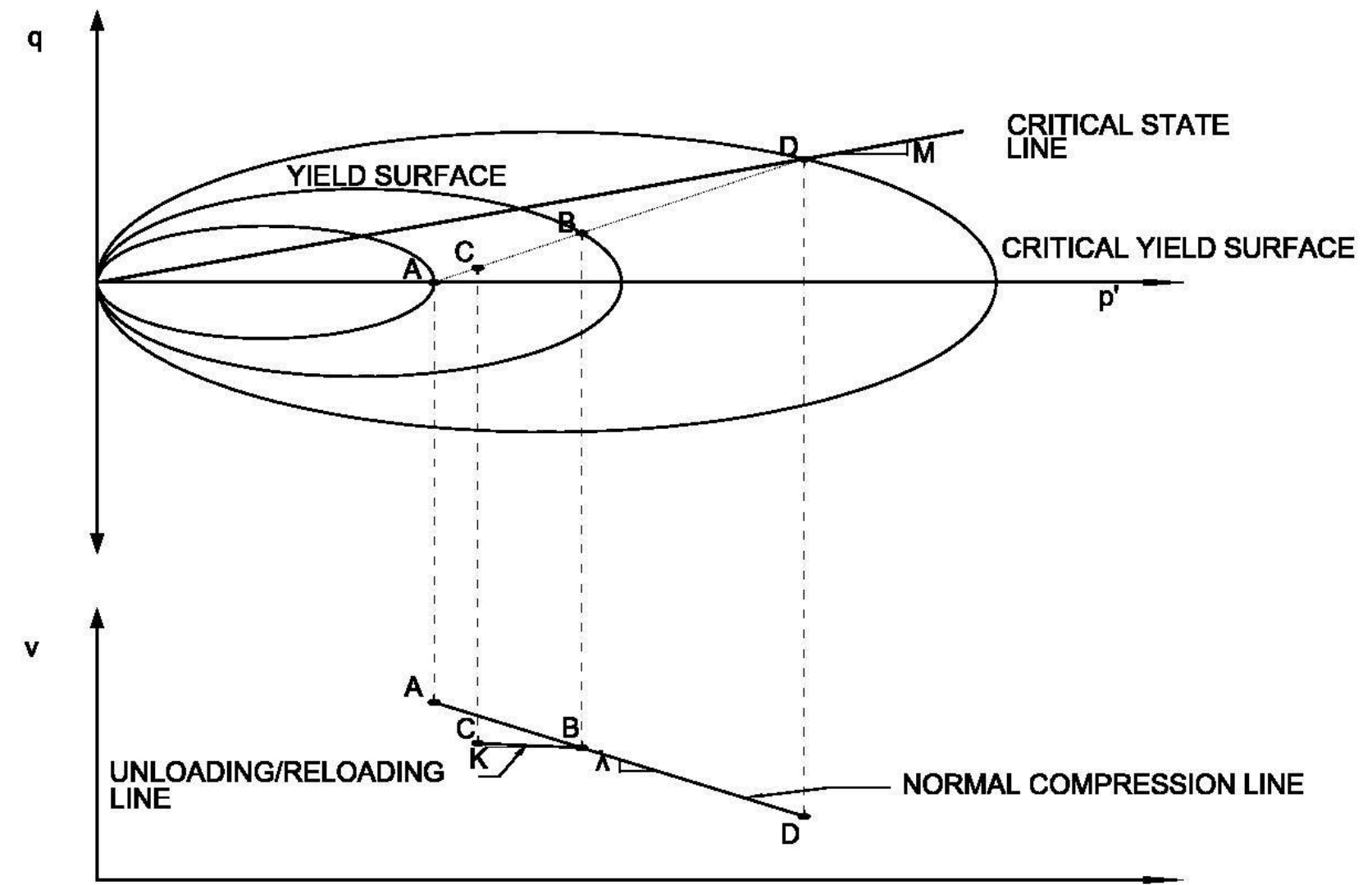

In $p^{\prime}$

Figure 10 Modified cam clay model (MCC model) 
The gradients of the compression $(\lambda)$ and unloading-reloading $(\kappa)$ line are characteristic properties of a soil. The gradient of the critical state line (M) is also a characteristic property of a soil as it is a function of the friction angle $\left(\varnothing^{\prime}\right)$ (Equation (1)).

$$
M=\frac{6 \sin \emptyset^{\prime}}{3-\sin \emptyset^{\prime}}
$$

The Mohr-Coulomb model was used for K1SE Case A to represent the underlying pit wall material.

\subsection{Material parameters}

The material parameters for Criterion Pit are based on the results of Rowe Cell testing conducted on the tailings material by the University of Western Australia (UWA) in October 2001 (Bhattarai et al., 2001). The material parameters for K1SE Pit are based on the results of modified triaxial and consolidation testing conducted on the tailings material by SRC Laboratories in August 1995 (Soil and Rock Engineering Pty Ltd, 1996). The deposition of tailings into in-pit facilities is largely sub-aqueous, and sub-aerial once the tailings beach develops, minimising segregation generally creating isotropic tailings properties. Isotropic permeability has therefore been used in both cases.

The pit wall material in Case A of K1SE represents the area of pit walls disturbed by mining activity. This disturbance loosens the rock, effectively increasing the localised permeability of the pit wall, offering drainage pathways for moisture from the adjacent deposited tailings through the disturbed rock in the pit wall face adjacent to the deposited tailings and in the disturbed zone of rock immediately behind the pit face. The presence of this drainage path assists the consolidation of deposited tailings.

The key material parameters adopted for each case study are presented in Table 6.

Table 6 Tailings material properties

\begin{tabular}{llll}
\hline Parameter & K1SE Pit & Criterion Pit & K1SE Pit Case A (pit wall material) \\
\hline$\Lambda$ & 0.09 & 0.36 & - \\
$\mathrm{K}$ & 0.01 & 0.02 & - \\
$\mathrm{M}$ & 1.2 & 1.2 & - \\
$\mathrm{e}_{0}$ & 3 & 4 & - \\
$\mathrm{k}(\mathrm{m} /$ day $)$ & $8.64 \times 10^{-4}$ & $3.46 \times 10^{-3}$ & $8.64 \times 10^{-3}$ \\
\hline
\end{tabular}

\subsection{Calculation}

Initial conditions of the PLAXIS ${ }^{\circledR}$ files for Criterion and K1SE Pits were of an empty pit with groundwater at the base of the pit. K1SE Case A consisted of an empty pit with a $1 \mathrm{~m}$ section around the edge representing the disturbed zone in the pit walls. Two stages were used for all cases. Stage 1 is the 'construction phase' with tailings deposited to the final tailings level and the time specified as the number of day's deposition occurred. Stage 2 is the consolidation phase. The tailings consolidate until excess pore pressure has reached a minimum of $1 \mathrm{kPa}$. At this stage consolidation is assumed complete, producing the results of final settlements.

\section{Results}

The PLAXIS ${ }^{\circledR}$ results produce a total settlement including settlement during deposition and post-deposition settlement. The total settlement predicted by PLAXIS ${ }^{\circledR}$ is $13.5 \mathrm{~m}$ for K1SE and $8.2 \mathrm{~m}$ for Criterion. Refer to Figures 11 and 12 for PLAXIS ${ }^{\circledR}$ results. 


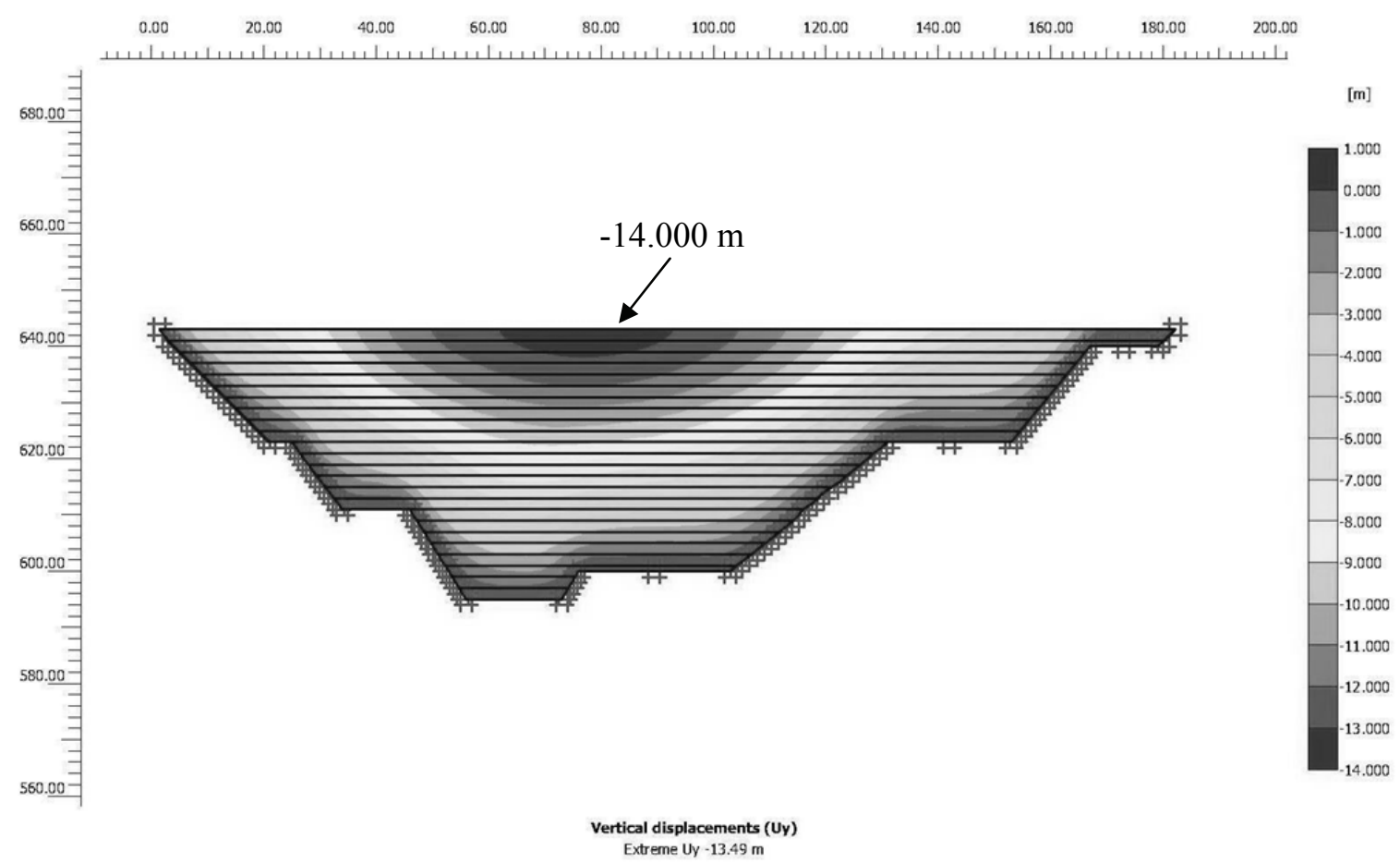

Figure 11 K1SE Pit total settlement (including deposition and post-deposition settlement)

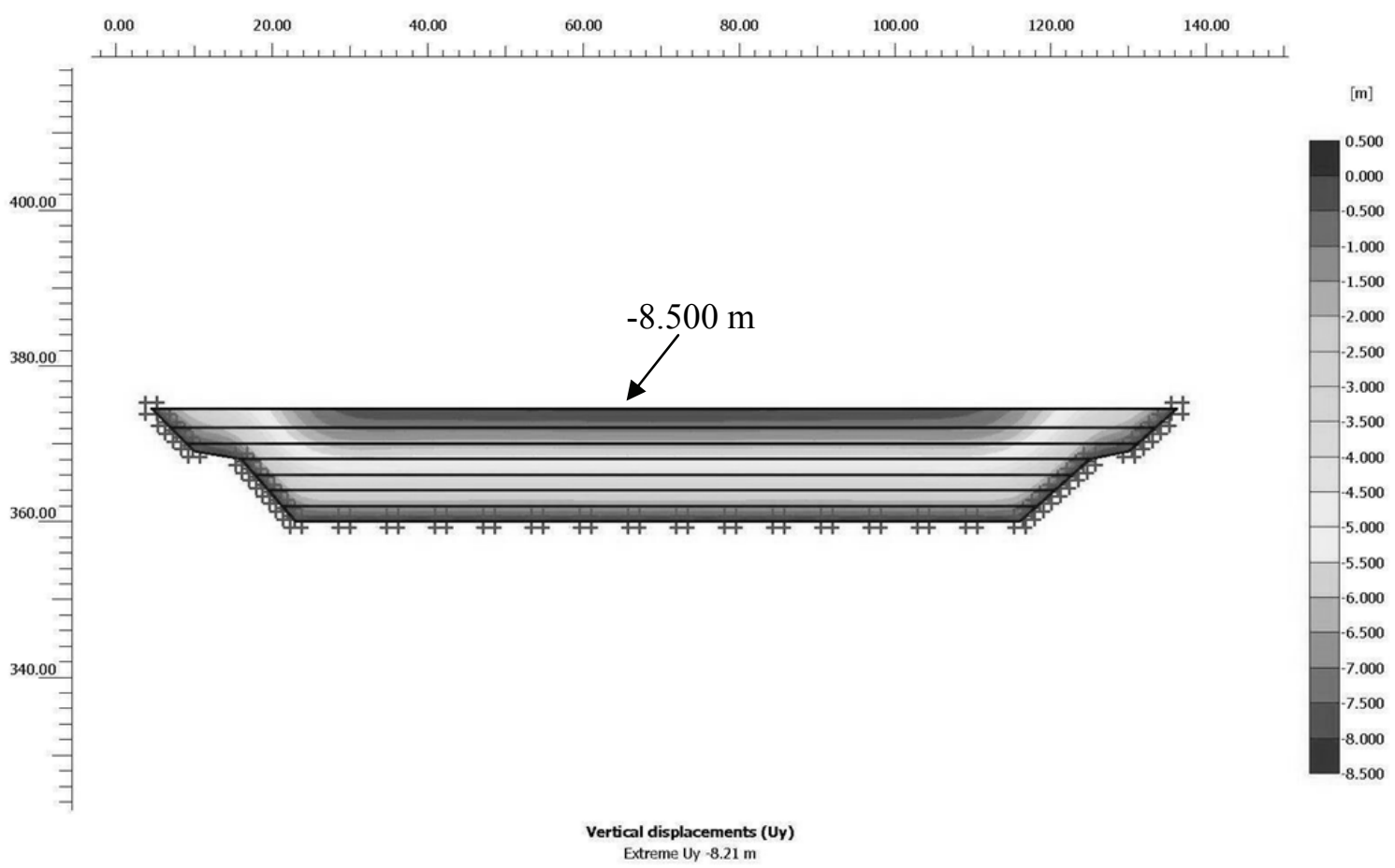

Figure 12 Criterion Pit total settlement (including deposition and post-deposition settlement)

The settlement that occurred during deposition was estimated to be $6.4 \mathrm{~m}$ for K1SE ( $6.6 \mathrm{~m}$ for K1SE Case A) and $3.6 \mathrm{~m}$ for Criterion. The lower permeability pit wall material encourages a higher amount of settlement to occur during deposition. This decreases the time period for consolidation post-deposition, in the case of K1SE by approximately 1 month. The post-deposition settlement was estimated to be $7.1 \mathrm{~m}$ for K1SE ( $6.9 \mathrm{~m}$ for K1SE Case A) and $4.6 \mathrm{~m}$ for Criterion Pit. 
The maximum surface settlement results achieved by PLAXIS ${ }^{\circledR}$ are very similar to the consolidation observed in the field. PLAXIS ${ }^{\circledR}$ modelling is an effective way to predict the settlement and time period for consolidation. The available data indicates completion of consolidation of K1SE Pit in less than three years, and Criterion Pit is less than five. The PLAXIS ${ }^{\circledR}$ models indicate completion of consolidation of K1SE Pit in approximately one year (11 months for K1SE Case A) and Criterion Pit in less than two. Table 7 provides a summary of the results.

Table 7 Consolidation of K1SE and Criterion Pits

\begin{tabular}{|c|c|c|c|c|}
\hline \multicolumn{2}{|l|}{ Analysis } & \multirow{2}{*}{$\begin{array}{l}\text { K1SE Pit } \\
\text { Less than } 3\end{array}$} & \multirow{2}{*}{$\begin{array}{l}\text { Criterion Pit } \\
\text { Less than } 5\end{array}$} & \multirow{2}{*}{$\begin{array}{l}\text { K1SE Pit Case A } \\
\text { Less than } 3\end{array}$} \\
\hline Time for post-deposition & Field & & & \\
\hline & Finite modelling & 1 & 2 & 11 months \\
\hline \multirow{2}{*}{$\begin{array}{l}\text { Maximum surface } \\
\text { settlement - during } \\
\text { deposition (m) }\end{array}$} & Field & \multicolumn{3}{|c|}{ No information available } \\
\hline & Finite modelling & 6.4 & 3.6 & 6.6 \\
\hline \multirow{2}{*}{$\begin{array}{l}\text { Maximum surface } \\
\text { settlement - post } \\
\text { deposition }(\mathrm{m})\end{array}$} & Field & 4 & 4 & 4 \\
\hline & Finite modelling & 7.1 & 4.6 & 6.9 \\
\hline \multirow{2}{*}{$\begin{array}{l}\text { Post-deposition settlement } \\
\text { as a percentage of tailings } \\
\text { thickness (\%) }\end{array}$} & Field & 8 & 28 & 8 \\
\hline & Finite modelling & 15 & 32 & 15 \\
\hline Total settlement (m) & Finite modelling & 13.5 & 8.2 & 13.5 \\
\hline
\end{tabular}

Due to the lack of data available for both pits the exact time period for 'completion' of consolidation could not be determined and hence the time for consolidation predicted by PLAXIS $®$ is unable to be confirmed.

The authors consider the most effective technique for monitoring the surface of an in-pit TSF, during operation and post closure, is through regular, 12 monthly surveys of the tailings surface using reflectorless survey techniques. Such surveys also assist with reconciliation of the in situ dry density of the deposited tailings (dry tonnes of tailings deposited divided by the pit storage volume consumed). The practicalities are of course that mining companies are generally not inclined to undertake such surveys unless there is a demonstrated benefit.

A time period of less than three years, possibly only one year, is a reasonably short time frame for the mine operator to wait for the commencement of rehabilitation. The longer period of consolidation (less than five years, possibly only two years) for Criterion Pit is due to the low dry density, high fines content nature of the laterite nickel tailings.

The K1SE Pit was rehabilitated and now forms part of the natural landscape without further consolidation. Criterion Pit has not been rehabilitated.

The success of these in-pit storages is largely due to the high percentile water recovery and high evaporation rates. The cyclic deposition into K1SE Pit allowed the final maximum settlement to be reached in a smaller time period at the end of deposition due to the drying and consolidating periods between depositions. Effective water recovery during operation is considered to be a key element in maximising the consolidation.

\section{Design considerations}

In-pit facilities can be an economic and environmentally viable option for tailings storage. Areas where in-pit storage is beneficial:

- when pit voids are available

- in areas of poor water quality, or where groundwater contamination is unlikely to be an issue

- where land availability is restricted. 
Important considerations in the design and operation of an in-pit facility:

- pit geology: shear zones provide a seepage path which may cause issues with groundwater contamination or safety if other open pits are still working nearby

- cyclic deposition with other facilities: allows tailings to dry and consolidate throughout the tailings storage life; reducing the waiting period for rehabilitation at the end of deposition

- water recovery: essential to maximise the density, volume and consolidation rate. This may be in the form of a pontoon mounted pump, underdrainage, or both

- rehabilitation design: requires a self-draining rehabilitated surface to prevent water entering the low permeability tailings mass below.

The successful operation of an in-pit storage facility can provide many benefits to mine operators, such as:

- low cost due to minimal design, construction, operating, labour and rehabilitation works when compared to other tailings storage options

- environmentally beneficial as an unsafe void is filled and rehabilitated to its natural landform

- eliminates the land disturbance caused by an above ground storage

- provides high water re-usage for plant operation.

The risks of an in-pit tailings storage facility at design, operation and closure stages are as follows:

- failure to operate water recovery to a high standard results in poor consolidation and may take years before rehabilitation can commence

- seepage pathways through the pit walls may cause groundwater contamination or safety issues with pits operating nearby

- risk of the magnitude (settlement) and the time of consolidation causing problems with rehabilitation are considered to be very low if the facility is well managed.

\section{Conclusions}

Finite element modelling to predict consolidation of in-pit tailings provides a method to account for variables such as varying water table with time, variable pit geometry and the time for tailings deposition. The key factors affecting the time for consolidation to occur is the permeability of the tailings, drainage pathways, depth of pit and maximising water recovery. The amount of settlement is dependent on the tailings consolidation characteristics (such as $\lambda$ and $\kappa$ ). It is important to perform laboratory testing to assess these tailings properties in order to predict the amount and time of settlement in the design of an in-pit tailings storage facility.

\section{Acknowledgements}

The authors would like to thank Andy Fourie, The University of Western Australia, for his assistance in PLAXIS®, and Minara Resources for funding the testing at Criterion Pit in 2008.

\section{References}

Anstey, D.R. and Williams, D.J. (2007) Predicting Consolidation of In-Pit Tailings, Total Tailings Management, Australian Centre for Geomechanics, Perth, WA, 5-7 December 2007.

Bhattarai, B., Fahey, M. and Kroupnik (2001) Bulong Nickel Mine Tailings: Rowe Cell Testing, University of Western Australia.

Hammah, R. (2005) Description of Cam-Clay and Modified-Cam-Clay Critical State Strength Models, Rocscience.

Lane, J.C. (2000) In-pit Tailings Disposal Marymia Gold Operation: Case History, in GLRG Workshop Proceedings.

Luke, G.J., Burke, K.L. and O’Brien, T.M. (1988) Evaporation Data for Western Australia Technical Report No. 65, Salinity and Hydrology Branch, Division of Resource Management, Western Australian Department of Agriculture. 
Muir Wood, D. (1991) Soil Behaviour And Critical State Soil Mechanics, Cambridge University Press, USA, pp. 112-117.

Soil and Rock Engineering Pty Ltd (1996) Tailings Disposal - K1SE Pit, Geotechnical Assessment of Pit and Tailings Characteristics.

Soil and Rock Engineering Pty Ltd (1997) Tailings Storage Audit, Inspection and Management Review, Marymia Gold Project.

Soil and Rock Engineering Pty Ltd (2004) Leach Residue Storage Facilities and Evaporation Facilities, Annual Geotechnical Audit - 2004, Bulong Nickel Operations. 